\title{
Religião, Arte e Literatura: interfaces do Sagrado
}

\section{Alex Villas Boas*}

V. 5 - N. $9-2015$

*Editor da Teoliterária PUC SP

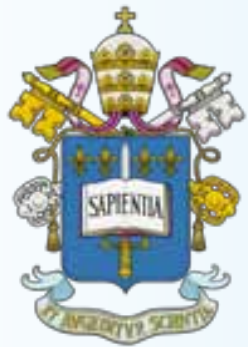

PUC-SP

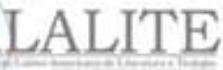

Associação Latino-americana de Literatura e Teologia ssa edição procurou privilegiar uma concepção ampla de poiésis, mais ligada aos antigos, porém ao mesmo tempo, que ilumina melhor o fenômeno contemporâneo no mundo da pesquisa em teologia, ciências da religião e outros saberes que tratam da questão que envolve o Mistério da Vida. A diferença entre os antigos e os modernos pode ser verificada no fato de que a especialização das áreas talvez tenha sua origem em tempos medievos com a proposta disciplinar organizacional do trivium e do quadrivium, estando ali já, entre outros elementos como outros já disseram, as origens da modernidade. Ao passo que para os modernos a classificação da arte se dava entre mímesis e poiésis, sem se ater tanto a uma epistemologia própria para cada forma de arte. 
Enquanto mímesis as artes (música, literatura, artes plásticas, teatro...) garantem a relação da arte com a realidade, ao passso que a poiésis provoca a admiração, espanto que faz pensar. Uma vez provocado a interioridade humana a se entender diante da obra, é o momento oportuno para o logos, enquanto proposta de um pensamento que verifica novas correlações na elaboração de uma consciência maior de si e do mundo em que habita. Tudo isso alarga a percepção da práxis. Essa capacidade de despertar o pathos para um nova práxis, talvez possa ser um dos elementos que permitem unificar as várias formas de, não somente expressar artisticamente a realidade, mas de recriar a relação que se tem com ela. Essa tarefa em si é uma arte!

Os modernos procuraram pensar suas especificidades, elaboram suas epistemologias próprias, na tentativa de definir o que é literatura, o que é arte, o que é teologia, o que é ciências da religião... São dois momentos importantes, mas que somente uma das posturas não atende de modo suficiente a complexidade da realidade. Sobretudo no que diz respeito ao Sagrado, enquanto parte da realidade não mensurável, e de difícil conceituação, "cabendo" quase que de modo apofático no conceito de Mistério.

Deste modo apresentar múltiplas interfaces [elemento que interliga ou proporciona uma interação entre dois âmbitos, a saber aqui, o Mistério e o ser humano que o contempla] propicia a compreensão de muitos ângulos do Sagrado nessa dinâmica de relação com a realidade em que o Sagrado se faz presente (mímesis), formas criativas de elaboração da percepção da realidade (poiésis) e o que isso ajuda a pensar (logos), e a pensar o modo de agir na vida (práxis).

Nesse sentido essas interfaces todas exercem uma função icônica de percepção da do Sagrado e da realidade nele contida, oferecendo imagens nas quais somos transformados nestas imagens que vão dando pistas à percepção como chaves de leitura, saindo do corredor estreito de pensar a questão do Sagrado, Deus, Religioso do corredor estreito e 
árido que deu exclusividade a ratio.

Há nessa proposta de reunir as interfaces do Sagrado, um aspecto mais amplo que é uma reeducação estética, enquanto formas de despertar e ampliar a sensibilidade, por vezes nos espaços tradicionais do Sagrado, por vezes em âmbitos inusitados. Em ambos os casos há que se ter uma reeducação do olhar, quer seja para que o aparente não perca sua função de processo pedagógico a contemplação de algo que se esconde, quer seja para que os inusitados espaços possam ser vistos com uma saudável desconfiança de que podem abrigar Algo que permanece Mistério e maior do que se poderia pensar até então, para um indivíduo acostumado a uma racionalidade cartesiana.

Assim nesta edição da Teoliterária se pretendeu apresentar uma compreensão sobre o papel dessas interfaces com a histórica de vários pesquisadores nacionais e internacionais. Vale destacar grupos de pesquisa em Religião, Arte e Literatura que tem amadurecido a discussão há algum tempo, em âmbito nacional e internacional, de onde são provenientes os vários autores desta edição:

-Asociación Latinoamericana de Literatura y Teología (ALALITE)

- Seminario Interdisciplinario Permanente de Literatura, Estética y Teología (SIPLET)

- Sociedad Argentina de Teología (SAT)

- Réseau de Recherche Adolphe Gesché, Louvain-la-neuve (RRAG)

- Sociedade Brasileira de Fenomenologia.

- Grupo de Estudos sobre Fenomenologia da Universidade de São Paulo (USP).

- GT de Religião, Arte e Literatura da Sociedade Brasileira de Teologia e Ciências da Religião (SOTER), liderados pelo Prof. Dr. Alex Villas Boas (PUC SP), Prof. Dr. Joe G. dos Santos (UFS) e pelo Prof. Dr. 
Antonio Cantarella (PUC Minas).

- Membros dos dois únicos grupos de pesquisa registrados no $\mathrm{CNPq}$ (Centro Nacional de Desenvolvimento Científico e Tecnologia), a saber o Teopoética - Estudos comparados entre Teologia e Literatura, da Universidade Federal de Santa Catarina (UFSC), liderados pela Profa. Dra. Salma Ferraz e pelo Prof. Dr. Antonio Carlos de Melo Magalhães na área de Letras, e o LERTE - Grupo de Pesquisa em Literatura, Religião e Teologia da Pontifícia Universidade Católica de São Paulo (PUC SP), liderado pelo Prof. Dr. Antonio Manzatto e Prof. Dr. Alex Villas Boas, na área de Teologia".

Também queremos destacar que essa edição vem ao encontro da criação da primeira Sessão Temática de Diálogo entre Religião, Arte e Literatura no V Congresso da Associação Nacional de Pós-graduação e Pesquisa em Teologia e Ciências da Religião (ANPTECRE) coordenados pelo Prof. Dr. Alex Villas Boas (PUC SP), Prof. Dra. Cleide Oliveira da Faculdade de Filosofia e Teologia dos Jesuítas (FAJE) e pelo Prof. Dr. Antonio Cantarella, da Pontifícia Universidade Católica de Minas Gerais (PUC Minas) $)^{2}$.

A discussão que vem sido ampliada por estes e tantos outros fóruns de discussão permite exatamente uma dupla possibilidade de abordagem do Sagrado em lugares inusitados como o texto de Salma Ferraz e André Luiz da Silveira (UFSC), Manifestações Humorísticas Subversivas a partir do Texto Bíblico: Um Panorama que aborda como o lúdico tem sido um lugar contemporâneo que abriga a questão do Sagrado, o trabalho de Juan Quelas (UCA) sobre "El revés de la trama”. La soledad y el anhelo del encuentro en un tema de Bersuit Vergarabat, uma banda de rock argetina. Mais ligado a literatura, o tema do Sagrado aparece em múltiplas faces como nos trabalhos de Neide Boechat (Faculdade de Bento/UNIFAI/USP), O Filósofo e o "Poeta maldito" em uma análise do

1. Disponível em < http://dgp.cnpq.br/dgp/faces/consulta/consulta_parametrizada.jsf >.

2. Disponível em < http://anptecre.pucpr.br/grupos-tematicos/>. 
Belo Superior feita por Jean Paul Sartre em Baudelaire; Marcio Capelli (PUC Rio) que apresenta um Sagrado "às avessas" em $A$ teologia às avessas de José Saramago em Caim e José Renato Santos (UMESP) com Rastros do sagrado: O encontro entre literatura e teologia em Nikos Kazantzákis apresentando uma poética contemporânea do Sagrado.

Também os lugares tradicionais, digamos assim, foram revisitados, como nos trabalhos de Wilma De Tommaso (Ciências da Religião - PUC SP) em suas Reflexões sobre o Mistério na Arte Sacra, distinguindo Arte Sacra de Arte Religiosa; Carin Zwilling (Teologia PUC SP/ECA USP) com Santa Cecília - arte e devoção através da música e sua abordagem do Sagrado a partir da estética musical.

$\mathrm{Na}$ Sessão de Artigos com Temas Livres está o trabalho de Maria José do Amaral (SOTER/Teologia PUC SP), Um Tratado para o Amor, sobre o amor cortês e a questão de Deus. A edição também consta com o relato de pesquisa de Hernán Pablo Fanuele (UCA), Entre la ficción transgresora y la historia - La refiguración evangélica del acontecimiento "Jesucristo" o Persuadir desde la tarea narrativa mimética dialogando com Paul Ricoeur e Adolph Gesché, e com a entrevista com Gilmar de Carvalho, um importante biógrafo do Patativa do Assaré, concedida a Emerson Scarbelotti e Antonio Manzatto (PUC SP) e a resenha de uma obra muito interessante a respeito de Dom Pedro II, como tradutor imperial e as referências que o mesmo tinha, entre outras de Dante Alighieri, feitas por Patrícia Leonor Martins e Elaine Leonor Martins (UFSC).

Por fim, dada a perda inestimável que tivemos da amiga e pesquisadora em teologia e literatura Agustina Serrano Pérez, a Teoliterária e a ALALITE lhe prestam uma singela, porém sincera homenagem.

Esperamos que essa edição ajude-nos a pensar as interfaces do Sagrado que nos doam novas lógicas existenciais, de modo a sermos transformados nessas imagens de claridade em claridade, como diria um moderno poeta theologus do medievo ${ }^{3}$.

3. Tomás de Aquino, Suma contra os Gentios, Livro IV, cap. XXII. 